\title{
SERVER PORTABLE BERBASIS RASPBERRY PI SEBAGAI MEDIA PEMBELAJARAN DI POLITEKNIK NEGERI BALIKPAPAN
}

\author{
Ali Abrar ${ }^{1 *}$, Qory Hidayati ${ }^{2}$, Paris Pandu ${ }^{3}$ \\ 1, 2 Jurusan Teknik Elektronika, Politeknik Negeri Balikpapan, \\ ${ }^{3}$ Mahasiswa Tingkat Akhir Politeknik Negeri Balikpapan \\ *e-mail : ali.abrar@poltekba.ac.id
}

\begin{abstract}
The digital age are growing rapidly, spurred each individual to adapt using technology in daily activities. The most frequently found today is the usage of a server computer. Not only in the company or a large institution, even now server computer are being used in homes. Today the terms such as network-attached storage and in home streaming are well known. To adapt with current technological advances, students should be able to set up a simple server computer that can be used at home. However, due to the limitations of existing devices on campus, students can't practice on setting up a server computer. The alternative is to use Raspberry $P i$. Raspberry Pi is a mini computer with a cheap price which is expected to help in the learning of server and network installation. Raspberry Pi can be installed with Linux based operating system which is open source operating system so it can be distributed and obtained freely. Then Raspberry Pi will be installed with server supporting software such as samba and apache. Samba used for file server application and apache used for web server application.
\end{abstract}

Keyword : Raspberry Pi, Linux, Server, Samba, Apache

\begin{abstract}
Abstrak
Perkembangan zaman digital semakin pesat, memacu setiap individu beradaptasi untuk menggunakan teknologi dalam kegiatan sehari-hari. Yang paling sering dijumpai saat ini adalah penggunaan komputer server, tidak hanya di perusahaan atau instansi besar bahkan komputer server kini digunakan di rumah. Kini istilah seperti network-attached storage dan in-home streaming sudah cukup di kenal. Untuk beradaptasi dengan kemajuan teknologi saat ini, mahasiswa seharusnya minimal dapat menginstalasi komputer server sederhana yang dapat digunakan di rumah. Namun karena keterbatasan perangkat yang ada di kampus, mahasiswa belum bisa belajar menginstalasi server. Alternatifnya adalah menggunakan Raspberry Pi. Raspberry Pi yaitu sebuah komputer mini dengan harga yang murah diharap dapat membantu dalam pembelajaran instalasi server dan jaringannya.

Raspberry Pi dapat di instalasi dengan sistem operasi berbasis Linux yang merupakan sistem operasi open source sehingga tentunya bisa disebarkan dan didapat secara bebas. Lalu di-install dengan program pendukung server seperti samba dan apache. Samba digunakan untuk aplikasi file server dan apache untuk aplikasi web server.
\end{abstract}

Kata kunci : Raspberry Pi, Linux, Server, Samba, Apache

\section{Pendahuluan}

Seiring dengan perkembangan teknologi jaringan komputer yang semakin pesat dan cepat, kebutuhan akan pemahaman dan media belajar mengajar yang mendukungnya menjadi suatu keharusan. Perangkat Raspberry pi yang dikenal dengan sebutan "kumputer mini seukuran kartu" membawa pengaruh terjadinya proses transformasi komputer konvensional ke bentuk yang lebih smart
(Mobile) dan terbuka (Open), baik secara hardware maupun softwarenya. Saat ini Raspberry Pi sudah banyak digunakan oleh masyarakat dunia, terbukti dengan banyaknya implementasi Raspberry Pi yang mendukung era Internet of thing ataupun Internet of Everything.[1]

Politeknik Negeri Balikpapan, sebagai perguruan tinggi baru yang belum memiliki banyak fasilitas di bidang TIK, dalam Rencana Strategisnya telah 
menetapkan sasaran mutu yang ingin dicapai di antaranya adalah menghasilkan lulusan yang menguasai aplikasi Teknologi Informasi.

Untuk mencapai sasaran tersebut, salah satu program yang dicanangkan adalah program penguatan sistem pembelajaran dan layanan terhadap mahasiswa dengan sasaran tersedianya fasilitas dan peralatan laboratorium secara bertahap. Oleh sebab itu dengan adanya penelitian ini bermaksud membuat Server Portable Untuk Network Simulator Menggunakan Raspberry $P i$ diharapkan dapat membantu untuk mengurangi kendala khususnya kalangan mahasiwa untuk memiliki komputer server dengan harga yang terjangkau.

\section{Metoda Penelitian}

Metoda yang dipakai dalam penelitian ini berupa langkah kerja serta rangkaian kegiatan sebagai berikut :

1. Melaksanakan studi literatur yang materinya berkaitan langsung dengan usulan kegiatan penelitian

2. Pengembangan Raspberry Pi Server

Dalam pengembangan Raspberry Pi Server ini, metode yang digunakan adalah SDLC (System Development Life Cycle) yang memiliki beberapa tahapan pengembangan. Mulai dari instalasi, konfigurasi sampai kepada proses pengujian sistem yang dibuat.[2]

\subsection{Spesifikasi Raspberry Pi 2}

Adapun spesifikasi Raspberry $\mathrm{Pi}$ yang digunakan dalam pengujian adalah :

1. CPU Quad Core $900 \mathrm{MHz}$

2. Ram 1 GB (terbagi dengan GPU)

3. 4 USB PORT 2.0

4. 1 10/100Mbps Ethernet port

5. Power Source $5 \mathrm{~V}$ via Micro USB

2.2 Perancangan Topologi Jaringan
Berikut adalah skema topologi jaringan sederhana yang penulis gunakan pada instalasi dan pengujian server portable Raspberry Pi, dimana pada tahap instalasi digunakan topologi client-server dengan alamat ip statik sedangkan pada tahap pengujian menggunakan topologi star dan client-server dengan alamat ip dhcp.

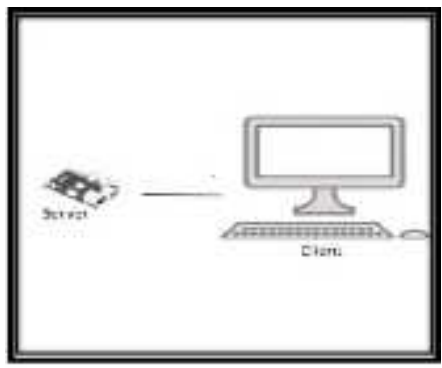

Gambar 1 Topologi Client-Server

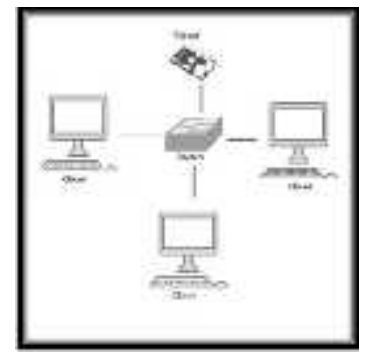

Gambar 2 Topologi Star

\section{Hasil Penelitian}

\subsection{Pengujian DHCP Server}

Ketika Raspberry Pi dihubungkan dengan komputer client secara otomatis akan memberikan alamat IP. Dengan range 192.168.10.3-192.168.10.29 dan akan mendapat nama domain raspiserver

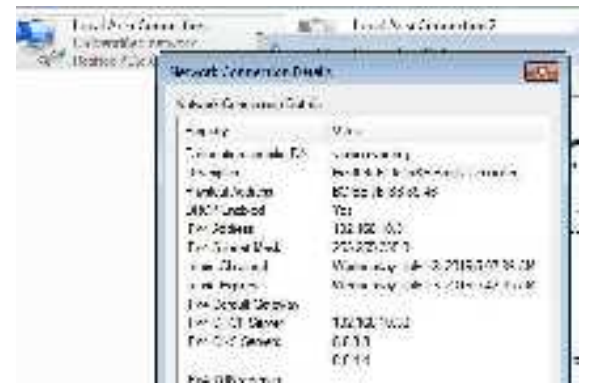

Gambar 3 DHCP IP dari Raspberry Pi

Lalu ketika dicek melewati log terminal akan terlihat client-client yang 
merequest alamat IP. Perintah yang digunakan adalah "sudo tail /var/log/syslog"[3]

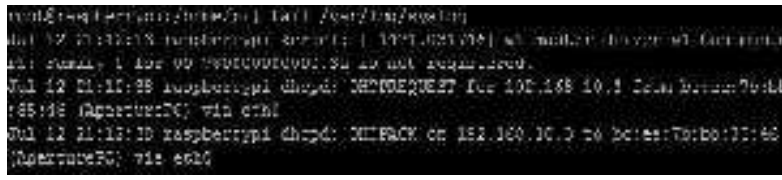

Gambar 4 DHCP log

\subsection{Pengujian Web Server [4]}

Web server akan otomatis berjalan setelah instalasi apache2. Pengujiannya adalah dengan membuka web tersebut melalui web browser dengan ip address dari Raspberry Pi. Untuk hasil konfigurasi kali ini addressnya adalah seperti gambar 5 dibawah ini.

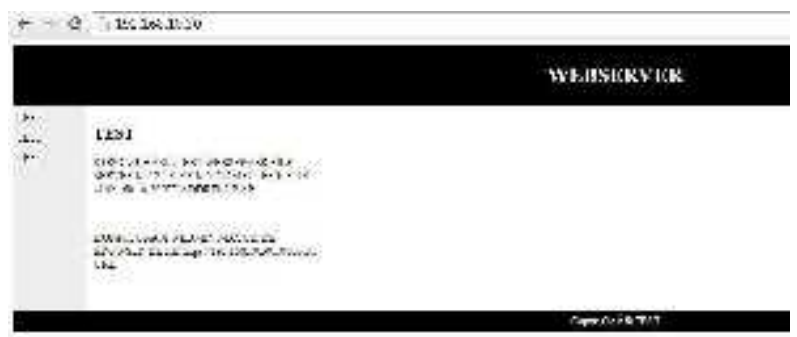

Gambar 5 Web server test

Akan tampil halaman web yang telah dimodifikasi tadi atau web default apache yang bertuliskan it works.[5] Namun web tersebut adalah web statik, untuk pengujian web dinamis bisa diuji dengan cara membuat sebuah file php. Dengan perintah "sudo nano /var/www/phpinfo.php”.[6]

\subsection{Pengujian Jaringan dan File Server \\ Pengujian dilakukan dengan} mengunakan 1 switch cisco catalyst 2960 plus dan 3 perangkat komputer client yang mengakses Raspberry pi sebagai server secara bersamaan. Untuk penggunaan ringan seperti web server masih berjalan cukup lancar begitu pula dengan pengujian selanjutnya yakni penggunaan file server secara bersamaan.[7]

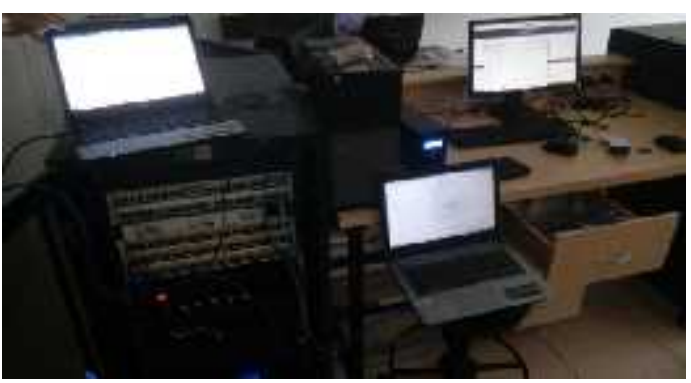

Gambar 6 Pengujian Jaringan Client Server menggunakan Raspberry Pi

\section{Kesimpulan}

Berdasarkan hasil perancangan, pengujian dan pembahasan mengenai server portable Raspberry P $i$, beberapa hal yang dapat diimpulkan adalah :

1. Raspberry Pi dapat dijadikan komputer yang berfungsi selayaknya server, dibandingkan dengan komputer server konvensional biaya yang dikeluarkan selama beroperasi jauh lebih murah.[8]

2. Sistem Operasi Raspberry $\mathrm{Pi}$ tidak membutuhkan lisensi khusus karena menggunakan Raspbian Wheezy yang masih termasuk dalam varian Debian linux.[9]

3. Meskipun tidak dapat menggantikan server yang sebenarnya, Raspberry $\mathrm{Pi}$ dapat dijadikan alternatif pengganti khususnya untuk pembelajaran bagi mahasiswa/i.

\section{Saran}

Pada perancangan dan pengujian server portable Raspberry Pi berbasis linux ini masih terdapat kekurangan. Beberapa hal yang dapat dijadikan saran pada rancangan server portable ini adalah:

1. Perlu dilakukan update/upgrade secara berkala, baik dalam sisi hardware dan software untuk mendapat perbaikan bug dan menambah kestabilan software.

2. Diperlukan menggunakan case untuk Raspberry $\mathrm{Pi}$ karena ukurannya yang kecil tentunya Raspberry $P i$ adalah komputer yang ringkih dan tanpa 
adanya case board Raspberry akan mudah kotor.

3. Raspberry $P i$ sebaiknya diletakkan di ruangan yang sejuk atau dekat denngan pendingin karena Raspberry Pi tidak memiliki cooler apalagi jika Raspberry $P i$ digunakan nonstop sebagai server.

4. Sebaiknya tidak menyalin file besar secara bersamaan dengan pengguna lain dari server, karena prosesnya akan lebih lama.

\section{Daftar Pustaka}

[1] Aaron Asadi, Ross Andrews, (2015) "Raspberry Pi The Complete Manual", Imagine Publishing Ltd., United Kingdom

[2] Eben Upton, Gareth Halfacree (2012) "Raspberry Pi User Guide", John Wiley \& Sons Ltd., United Kingdom

[3] Eric Filson, Eric Rosebrock (2004) “ Setting Up LAMP : Getting Linux,
Apache, MySQL, and PHP working together", Sybex., San Francisco, London

[4] Golden, Rick Raspberry Pi Networking Cookbook Pack Publishing BirminghemMumbay 2013

[5] Kula, Piotr J. Raspberry Pi Server Essentials Pack Publishing BirminghemMumbay 2014

[6] Raihana Rahma Fadhilah, (2015) "Pengenalan Debian, ilmu komputer.com Raspberry", Tech, Learn And Make With Raspberry. Retrieved from https://www. Rasperry.org/

[7] Maik Schmidt, (2014) "Raspberry Pi A Quick Start Guide $2^{\text {nd }}$ Edition", The Pragmatic Bookself., Dallas, Texas

[8] Rizal Rahman, (2013) "Mahir Administrasi Server dan Router dengan Linux Ubuntu Server 12.04 LTS"

[9] Simon Monk, (2014) : Raspberry Pi Cookbook, O'Reilly Media Inc., United States of America 